\title{
AKI KAURISMÄEN NÄKEMYS ROBERT BRESSONIN ELOKUVATEOKSISTA
}

Jatko-opinnoissani tutkin ranskalaisen elokuvaohjaajan Robert Bressonin ja suomalaisen elokuvaohjaajan Aki Kaurismäen yhteyksiä. Tarkemmin sanoen haluan selvittää, mitä Kaurismäki on ottanut omiin elokuviinsa juuri Bressonilta ja miksi. Tältä kannalta kiinnostava on Kaurismäen teksti "Robert Bresson - Susi" (Quandt 1998, 561-562; von Bagh 2006, 90), jossa hän valottaa näkökulmaansa Bressoniin. Hän kirjoittaa: "Niin yksinäinen kuin Mr. Bresson onkin kirotussa ammatissaan, hän ei silti ole täysin eristetty. [...] Kuinka syvälle Bresson haluaakin kätkeytyä katolisen armon käsitteiden uumeniin, hän ei sittenkään voi kiistää sitä, että hän on melodraamojen tekijä." (von Bagh 2006, 90.) Tämä väite on tarkasteluni lähtökohta. Hypoteesini on, että tämän tekstin avulla voidaan nostaa esiin Bressonia ja Kaurismäkeä yhdistäviä piirteitä ja avata niiden merkitystä.

Robert Bressonista on kirjoitettu paljon. Hänen teostensa vastaanotto on ollut hyvin moninaista, ja elokuvatutkimuksessa ne on nähty hyvin moniulotteisena tutkimuskohteena. Bressonin ura pitkien elokuvien ohjaajana ulottui vuodesta 1943 vuoteen 1983, ja hänen elokuviaan pidetään yleisesti mestariteoksina, jotka ovat vaikuttaneet vahvasti elokuvataiteeseen. Hän on kuuluisa omintakeisesta tyylistään ja erityisestä näkökulmastaan elokuvataiteeseen, jonka hän on esittänyt erityisesti vuonna 1975 julkaistussa teoksessaan Notes sur le cinématographe (suom. Merkintöjä kinematografiasta). ${ }^{1}$ Bressonin elokuvatyylin pääpiirteet ovat ilmeetön näytteleminen, tehokas ja elliptinen kerronnallinen rakenne, lukuisat askeettiset ja yksityiskohtaiset lähikuvat sekä tarkasti koottu ja käytetty äänimaailma. Hänen suuria teemojaan ovat muun muassa taistelu vapauden puolesta, uskontoon kytkeytyvä transsendenssi, sosiaalinen vieraantuminen ja modernin maailman pahuus (Prédal 1992). Teemojensa takia monet kriitikot ja tutkijat ovat kutsuneet Bressonia jansenistiksi Blaise Pascalin tapaan (Pönni 2005, 40-41). ${ }^{2}$

Bressonin elokuvien on katsottu edustavan armon fenomenologiaa (Bazin 1958) tai rakentavan uskonnollisen universumin (Ayfre 1964) ja niiden tyyliä on pidetty hengellisenä (Sontag 1964) tai transsendentaalisena (Schrader 1972). 1960-luvulta lähtien asiantuntijat ovat yrittäneet päättää, onko Bresson materialistinen vai abstraktinen ohjaaja, onko hänen elokuvissaan Jumalan läsnäoloa, minkälaista metafysiikkaa hän edustaa ja niin edelleen (Dahan 2004). Nykytutkimuksessa keskeisenä ideana on ollut, että hänen elokuvansa kertovat jotain olennaista modernista ihmisestä ja yhteis-

\footnotetext{
1 Käännetty suomeksi teoksessa Merkintöjä Robert Bressonista (Hyttinen \& al. 1989).

2 Jansenismi oli 1600-luvulla erityisesti Port Royal -luostarissa vaikuttanut katolinen teologinen suuntaus. Jansenismi sai vaikutteita erityisesti Augustinuksen uskosta ja filosofiasta. Muun muassa ennaltamäärääminen, ihmisen vapaa tahto ja Jumalan armo olivat tärkeitä teoreettisia ongelmia jansenisteille ja varsinkin Blaise Pascalille.
} 
kunnasta (Price 2011; Burnett 2016). Mielenkiintoista onkin, että omilla elokuvillaan ja teksteillään Aki Kaurismäki osoittaa ymmärtävänsä Bressonin teoksia, teemoja ja tyyliä erittäin hyvin - kenties jopa paremmin kuin Bresson-tutkijat. Kaurismäellä on oma, erikoinen, uudistava näkökulma Bressonin elokuviin. Tässä katsauksessa pohdinkin, millainen on Kaurismäen näkemys Robert Bressonin teoksista.

\section{Robert Bresson - melodramaattinen susi}

Aki Kaurismäen mielestä Bresson on erilainen kuin muut ohjaajat, ja hän on juuri siksi yksi suurimmista melodraamaelokuvien ohjaajista. Tekstissään Kaurismäki kutsuu Robert Bressonia melodraaman ohjaajaksi, joka on mennyt niin pitkälle omassa tyylilajissaan, ettei hänen elokuvissaan ole enää melodraaman elementtejä. Väite viittaa sekä visuaaliseen tyyliin että melodraaman perinteisiin teemoihin. Tarkalleen se tarkoittaa, että Bressonin elokuvissa on siis elementtejä, jotka lähentävät niitä melodraamaan siitä huolimatta, että ne eivät ole melodraamoja sanan tavanomaisessa merkityksessä. Toisin sanoen "Bresson on yksinäinen" (von Bagh 2006, 90), hän rakentaa oman melodraamansa. Seuraavassa pyrin pohtimaan, mitä tämä käytännössä voisi tarkoittaa.

Françoise Zamour määrittelee melodraaman elokuvataiteessa tyylilajiksi, jossa on yleensä dramaattinen kerrontarakenne, voimakkaita tunteita ja uhrihahmo. Melodraama pyrkii tunnistamaan jotakin tunnusomaista ihmiskunnasta ja maailmasta yrittämättä olla aina realistinen tai kiinni totuudessa. Näin katsoja on mukana kokemassa uhrin tarinaa ja samastuu päähenkilöön äärikokemusten kautta. Melodraama oli suosittu 1900-luvun alkupuolella, mutta Zamourin mukaan monissa moderneissa elokuvissa esiintyy edelleen sille tyypillisiä elementtejä. Melodraamaelokuva näyttää päähahmon, joka taistelee, yrittää olla moraalinen ja saada tilaa itselleen yhteiskunnassa. Tyylilaji ei välttämättä yritä olla realistinen, vaan kerronnallaan se pyrkii ennen kaikkea liikuttamaan katsojia ja täten vaikuttamaan siihen, miten katsojat yhteiskunnan näkevät. Muita lajityyppejä enemmän se rakentaa sosiaalisia ja moraalisia näkökulmiaan emotionaalisilla efekteillä. (Zamour 2016, 21-68.)

Kaurismäen näkemys Bressonin melodramaattisuudesta on tuore ja erittäin vakavasti otettava etenkin, kun huomioidaan melodraaman sosiaalinen aspekti. Bressonin elokuvien henkilöhahmot kamppailevat ja kapinoivat eri tavoin yhteisöään vastaan, kuten taskuvaras Michel tai maailmaan pettynyt Charles. Jokainen hahmo on myös ihmiskunnan pahuuden uhri, kuten pahoinpidelty aasi Balthazar, raiskattu Mouchette tai dominoitu suloinen nainen. Tyypillistä Bressonille on kuvata marginaalista henkilöä pyrkimässä tukahduttavasta yhteiskunnasta jonkinlaiseen paratiisiin, utopiaan, jossa hän olisi vapaa. Bressonin teoksista löytyy myös sekä yhteiskunnallisia dramaattisia tarinoita että hahmojen voimakkaita tunteita. Rahassa (1983) nuori ja rehellinen työläinen Yvon joutuu petoksen uhrina vankilaan, menettää perheensä ja yrittää tehdä itsemurhan. Vankilasta päästyään hänestä on tullut yhteiskunnan synnyttämä hirviö, joka murhaa ensin hotellinomistajapariskunnan ja lopulta kokonaisen perheen ennen kuin antautuu poliisille. Kutsumalla Robert Bressonia melodraaman ohjaajaksi Kaurismäki muistuttaa, että paljon on vielä sanomatta Bressonista.

Teemojen lisäksi Bressonin elokuvissa voi nähdä tyylillisiä vaikutteita melodraamasta. Sakari Toiviainen toteaa: "Melodraama muodostuu sanoista draama plus melos eli musiikki. Tässä alkuperäisessä ja kirjaimellisessa merkityksessään melodraama on dramaattinen kertomus, jossa musiikkisäestys korostaa emotionaalisia efektejä." (Toiviainen 1992, 11.) Toisin sanoen melodraamoissa musiikki, kuten koko ääniraita, on tärkeä elementti elokuvan kerronnallisessa struktuurissa, sillä 
ääniraita on olennainen merkitsijä diskursiivisille efekteille (esimerkiksi junan äänet Kuolemaantuomittu on karannut elokuvassa). Monet tutkijat ovatkin huomanneet, kuinka ääniraita on tärkeä sekä Bressonille (Dahan 2004, 45-50) että Kaurismäelle (Pecquet 2001, 119-128). Kummankin teoksissa, kuten melodraamaelokuvissa yleisesti, äänet auttavat ymmärtämään hahmon subjektiivista näkökulmaa ja tunteita. Lisäksi Bressonin ja Kaurismäen elokuvat muistuttavat melodraamaelokuvia siinä, että ne eivät yritä olla realistisia vaan ennen kaikkea kerronnan rakenteeltaan tehokkaita. Esimerkiksi Sirkin elokuvaa Suurinta elämässä (1959), Bressonin Mouchette, raiskattua (1967) ja Kaurismäen Tulitikkutehtaan tyttöä (1990) yhdistää kohtaus, jossa naispäähenkilöä läimäytetään kasvoille. Noiden elokuvapätkien yhteinen piirre on se, että niissä tärkeintä on sukupuolisen väkivallan ja valta-aseman näyttäminen, eikä realismille uskollinen näkökulma.

Lisäksi Kaurismäen ja Bressonin teokset ovat minimalistisesti rakennettuja - niissä nähdään ennen kaikkea kasvojen ja käsien lähikuvaa. Bresson ja Kaurismäki kuvaavat päähenkilöä lähikuvalla, kapealla terävyysalueella. Lavastus on minimalistinen ja tukahduttava. Tällöin katsoja on päähenkilön lähellä; hän ymmärtää ja kokee päähenkilön konfliktin, mutta ei samastu siihen. Molemmilla on hyvin melodramaattisia kertomuksia ja äärimmäisiä tilanteita (esimerkiksi Baltazarissa [1966] Marie päätyy rakastajattareksi ja lopulta prostituoiduksi rakkauden takia), jotka kuitenkin kerrotaan etäisellä ja neutraalilla tavalla. Mutta toisin kuin melodraamaelokuvissa, Bresson ja Kaurismäki eivät kuitenkaan vain näytä sosiaalisen uhrin tarinaa, vaan he myös antavat katsojan kokea tämän taistelun. Molemmat ohjaajat ylittävät melodraaman tyylin rajat, koska heidän elokuvalliset puheenvuoronsa modernista maailmasta ja yhteiskunnasta syntyvät katsojan mielessä montaasiperiaatteen avulla (Pönni 2005, 43). Tämä rakenne takaa sen, että jokainen elementti kuvassa ja äänessä on merkittävä. Se korostaa emotionaalisten efektien muodostumisessa katsojan aktiivista roolia, eikä vain samastumista päähenkilöön. Montaasiperiaatteen korostus näkyy sekä Robert Bressonin muistiinpanoissa (Bresson 1975) että Aki Kaurismäen keskustelussa Peter von Baghin kanssa Tulitikkutehtaan tytöstä (1990), jossa hän sanoo, ettei Iiris murhaa ketään, vaan katsoja kuvittelee sen, eli tappaa hahmot omassa mielessään (von Bagh 1999, 26-27).

Bresson ja Kaurismäki rakentavat tyylilajinsa melodramaattisten tarinoiden pohjalle tekemättä kuitenkaan varsinaisia melodraamaelokuvia. Paitsi että Bresson hyödyntää tyylilajissaan elementtejä melodraamasta, hänen kaksi ensimmäistä elokuvaansa olivat melodraamoja. Kaurismäki huomasi tämän ja käytti vuorostaan Bressonin tyylilajia. Kuten Kaurismäki (2006, 561-562) sanoo Bressonista: "Tosiasiassa tuskin onkaan missään taiteessa mitään tyyliä johon hän haluaisi yhdistyä." Bressonia ei voi liittää mihinkään, mutta Kaurismäki liittyy häneen ja jopa niin, että Kaurismäen hahmot muistuttavat Bressonin uhreja. Hahmojen marginaalisuus muodostuu kulmakiveksi: sekä Bresson että Kaurismäki käyttävät uhrihahmon tyyppiä, joka muistuttaa melodraaman genrestä mutta joka ei silti ole alkuperäisen kaltainen.

\section{Bressonin ja Kaurismäen susilauma - muodolliset yhteydet ja retoriset kaiut}

Monet suomalaiset kriitikot näkivät Bressonin läsnäolon Aki Kaurismäen ensimmäisessä elokuvassa Rikos ja rangaistus (1983). Pertti Lumirae kirjoitti vuonna 1983: "Mutta vaikka Kaurismäen (ja toisen käsikirjoittajan Pauli Pentin) temaattinen pohjavire ei olekaan bressonilaisen uskonnollinen, muistuttaa Rikos ja rangaistus silti visuaaliselta ilmiasultaan useita Bressonin elokuvia." (Lumirae 1983.) Kriitikot näkivät elokuvan muistuttavan Bressonin teoksia, koska näyttelijät eivät näyttele, päähenkilö yrittää pärjätä yhteiskuntaa vastaan ja elokuvassa on elliptinen kerrontarakenne. 
Yhteys vahvistui vuonna 1988, kun Ranskassa julkaistiin Kaurismäen Varjoja paratiisissa (1986). Tuolloin ranskalaiset eivät selvästi oikein tienneet, mikä on Suomi ja että suomalainen elokuvakulttuuri oli olemassa. Tietämättömyys Suomesta auttoi ranskalaisia kriitikkoja kuten esimerkiksi Claude-Marie Tremois (1990), Henri Béhar (1990) tai Paul-Louis Thirard (1996) katsomaan vain elokuvan formaalista rakennetta ja siten yhdistämään Kaurismäen Bressoniin. Lisäksi Kaurismäki myönsi pian haastatteluissaan, että Bresson oli hänelle todella tärkeä esikuva. Joskin hän myös vitsaili, että Bressonin elokuvat ovat eeppisiä toimintaelokuvia hänen elokuvaansa Tulitikkutehtaan tyttö (1990) verrattuna (Kyösola \& Leutrat 2001, 6). Syntyi vuosia kestänyt debatti siitä, oliko Kaurismäki Bressonin tai jonkun muun opetuslapsi. Lopulta ranskalaiset kriitikot päättivät, että Kaurismäki oli "auteur", samalla tavalla kuin Bresson.

On yksinkertaistavaa todeta, että Bresson ja Kaurismäki tekevät samanlaisia elokuvia pohtimatta kunnolla, mikä heitä yhdistää ja miten yhteys värittää tulkintaa. Kaurismäen näkökulma Bressoniin auttaa ymmärtämään, millaista ranskalaisohjaajan läsnäolo Kaurismäen elokuvissa on. Kaurismäen näkökulma on, että Bresson on melodraaman ohjaaja, vaikka hän piilottaa itseään uskonnon ja metafysiikan taakse. Mutta koska Kaurismäellä on oma kulttuuritaustansa, oma vanha ja melankolinen suomalainen näkökulmansa, hän näki Bressonissa jotakin, mitä muut eivät välttämättä nähneet. Toisin sanoen Kaurismäen subjektiivisen näkökulman takia hänen arvionsa Bressonin elokuvista oli erilainen kuin ranskalaisten. Kriitikot olivat oikeassa nähdessään Bressonin läsnäolon Kaurismäen elokuvissa, mutta he eivät ymmärtäneet Bresson-vaikutteiden luonnetta - sitä, että Kaurismäki tulkitsi Bressonin teoksia erilaisen prisman läpi. Onkin olennaista huomata, että Kaurismäen elokuviin sisältyy myös Bressonin arvostelua.

Asiaa voi lähestyä transnationalistisen metodologian kautta. Se on tärkeä apu pohdittaessa vastaanoton ja vaikutuksen roolia elokuvataiteen rakentumisessa ja auttaa näin myös ymmärtämään, miten Bressonin ja Kaurismäen elokuvateosten yhteyttä voidaan jäsennellä. Ymmärrän transnationaalisuuden samalla tavoin kuin Elisabeth Ezra ja Terry Rowden:

Transnationaalisuuden käsite auttaa meitä ymmärtämään paremmin niitä muuttuvia tapoja, joilla kasvava joukko erilaisten lajityyppien elokuvantekijöitä mieltää nykymaailman pikemminkin globaaliksi järjestelmäksi kuin joukoksi enemmän tai vähemmän itsenäisiä kansakuntia. (Ezra \& Rowden 2006, 1-2.)

Toisin sanoen transnationalismi auttaa näkemään niitä syvällisiä tapoja, joilla vastaanotto ja vaikutteet ovat mukana elokuvien luomisprosessissa. Olennaista on se, että elokuvat ovat teoksina moniulotteisia ja ne matkustavat helposti maailman ympäri. Kaurismäen erilainen näkökulma ja omat teokset auttoivat häntä ymmärtämään Bressonin teoksia uudella tavalla. Transnationalististen vaikutusten kautta Kaurismäen teokset ja niissä esitetyt yhteydet auttoivat avaamaan uudenlaisia näkökulmia myös Bressonin elokuviin. On esimerkiksi mielenkiintoista verrata Taskuvarasta (1959) ja Rikosta ja rangaistusta (1983) laajemminkin kuin vain kahtena erilaisena Dostojevskin adaptaationa. Tällä tavoin elokuvataiteen sisäinen keskustelu voi auttaa lisäämään ymmärrystä eri teoksista ja niiden tulkintaulottuvuuksista.

Erityisen kiinnostavaa on, että käyttämällä samantyyppistä merkitsijää (elliptinen, melodramaattinen ja minimalistinen kerrontastruktuuri, neutraali näytteleminen, lähikuvan ja lähiäänen käyttäminen ja niin edelleen), Bresson ja Kaurismäki antavat uudenlaisen mahdollisuuden ajatella marginaalia ja modernia ihmistä sekä elokuvataidetta. Boheemielämän (1992) ja Le Havren (2011) taitelija, katufilosofi ja humanisti Marcel Marx olisi hyvin voinut olla nuoruudessaan elokuvan Paholainen 


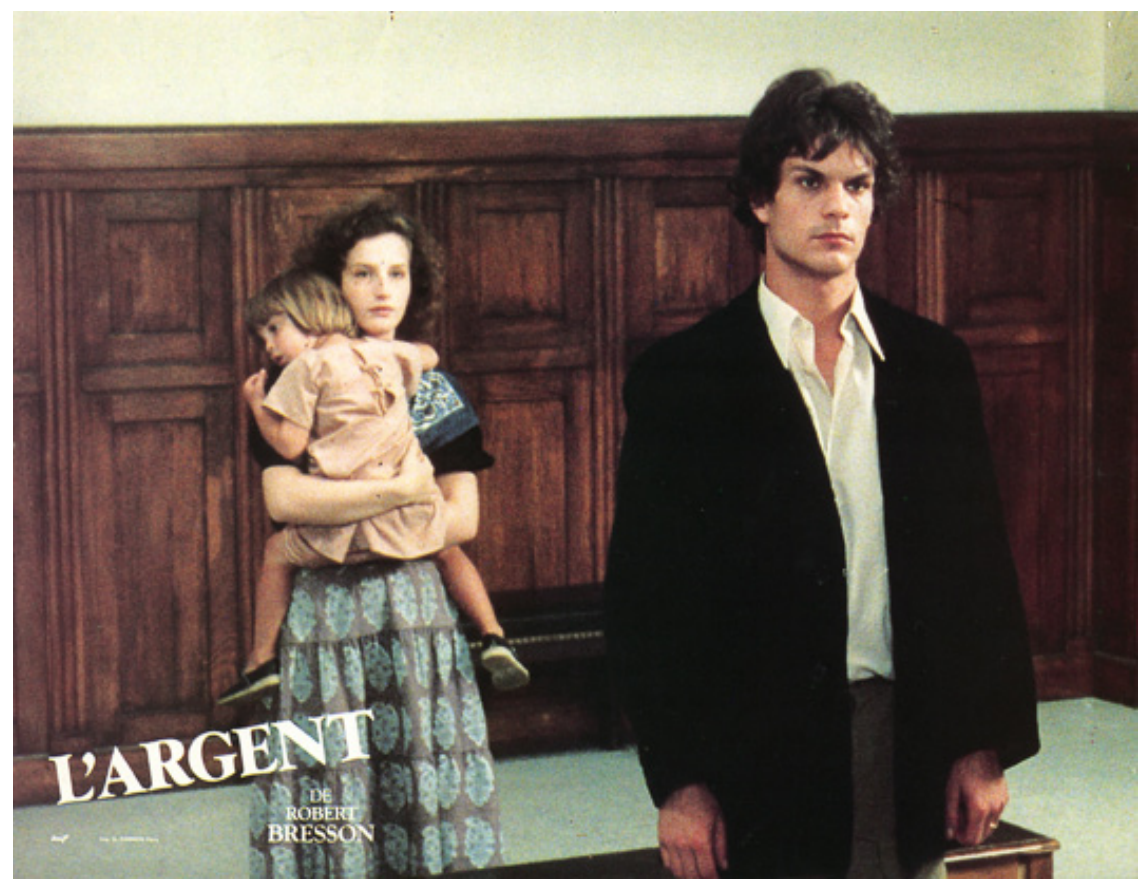

Bressonin viimeiset elokuvat, kuten Raha (1983), kommentoivat modernia yhteiskuntaa. Kuva: KAVI.

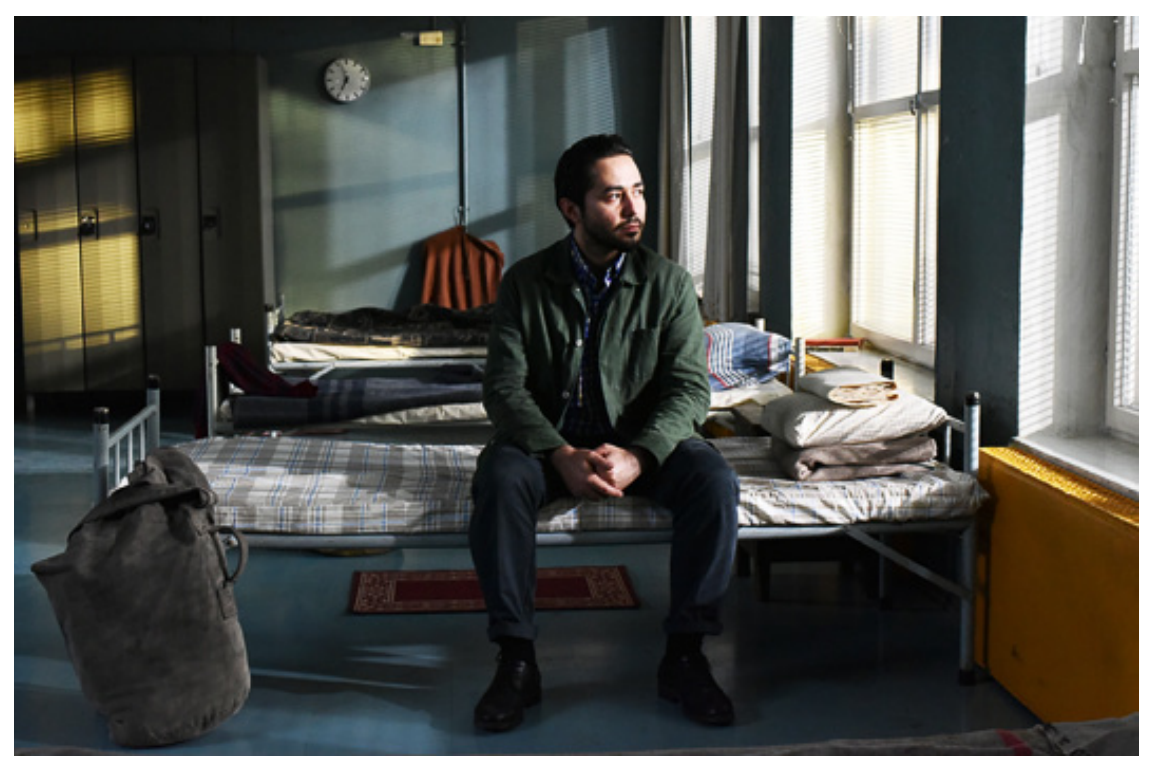

Kaurismäen teokset, kuten ohjaajan viimeisin elokuvaToivon tuolla puolen (2017), kommentoivat tämän päivän ongelmia ja järjestelmän kylmyyttä. Kuva: Malla Hukkanen @ Sputnik Oy.

luultavasti (1977) Charlesin tai Neljä yötä Pariisissa -elokuvan (1971) Jacquesin ystävä. Bresson halusi luoda erilaisen vaihtoehtoisen elokuvataiteen, jonka hän nimesi "kinematografiaksi". Kuten Andrew Nestingen (2013) toteaa, myös Kaurismäki yrittää rakentaa elokuva-taiteella vaihtoehtoisen näkökulman maailmaan ja oman tavan tehdä elokuvia. 
Molemmat ohjaajat siis rakentavat elokuvien kautta omia näkemyksiään maailmasta. Heitä ei voi ajatella ohjaajina ottamatta huomioon osallistumista nykypäivän maailmaan. Sen huomaa varsinkin Bressonin viimeisistä elokuvista Raha (1983) sekä Kaurismäen uudesta elokuvasta Toivon tuolla puolen (2017). Molemmat elokuvat kertovat nykyajan ongelmista ja modernin järjestelmän kylmyydestä. Tämä näkyy varsinkin tavassa, jolla molemmat ohjaajat esittävät poliisin ja oikeuslaitoksen, jotka asettuvat molempien elokuvien päähenkilöitä Yvonia (Raha, 1983) ja Khaledia (Toivon tuolla puolen, 2017) vastaan. Bresson ja Kaurismäki ovat marginaalisia ohjaajia, joilla on samanlainen tavoite. Molemmat rakentavat melodraamasta ponnistaen vaihtoehtoisia elokuvateoksiaan, jotka toimivat keskenään samalla tavalla, samoilla perustuksilla. Vaan miten ohjaajia sitten tarkemmin ottaen voidaan vertailla ja yhdistää toisiinsa?

\section{Perintö ja ylitys - isän ja pojan suhde}

Olen todennut, että Kaurismäki jatkaa Bressonin uhrihahmon käyttöä. Mutta hän menee myös pidemmälle, koska hän syventää Bressonin tyyliä. Näin Kaurismäen Laitakaupungin valoissa (2006) päähenkilö Koistinen yrittää sopeutua yhteiskuntaan ja olla aktiviinen henkilö yhteisössään samoin kuin ennen häntä yritti ja epäonnistui Ambricourtin pappi Bressonin Papin päiväkirjassa (1951). Molemmissa hahmoissa huomionarvoista on se, miten heidät kuvataan heidän yksinäisyydessään ja kuinka tärkeitä heidän katseensa ovat. Mutta toisin kuin ääniraidalta välittyvä papin näkökulma, Koistisen subjektiivisuuden ymmärtämiseen riittävät hänen katseensa suoraan kameraan lähikuvassa. Kaurismäki väittelee Bressonin kanssa ajan ja rajojen yli. Hän perii tältä paljon, mutta ei kuitenkaan ole tämän opetuslapsi. Kaurismäki tekee perinnöstä laajempaa ja omaansa. Bresson-tekstinsä viimeisessä virkkeessä Kaurismäki puhuu Bressonista kuin isästä tai mentorista - ja yleensä perijän tarkoitus onkin jatkaa eteenpäin ja rakentaa jotain parempaa. Lisäksi transnationalismin näkökulmasta voidaan havaita, että Bressonin ja Kaurismäen suhde toimii vastaavalla perinnön ja ylityksen periaatteella. Sen voi huomata erityisesti Kaurismäen tavoitteesta luoda elokuvissaan oma marginaalihahmonsa.

Kuten muun muassa Paul Schrader (1972), Amédée Ayfre (1964) ja myös Bresson itse haastatteluissaan (Bresson et al., 2013) toteavat, Bressonin tuotanto toimii uskonnon kautta. Tällä tarkoitan, että hänen päähenkilöt uskovat parempaan paikkaan, jossa marginaalissa olijat ovat ihmisiä niin kuin muutkin. He toivovat paikkaa, missä yhteiskunnallinen turhuus ja väkivalta eivät vallitse. Bresson antaa ymmärtää, että materiaalisen ja surkean maailman tuolla puolen on paratiisi. Tämä tuo mieleen Blaise Pascalin teoksen Les Pensées (Mietteitä, 1670) esittämän ajatuksen ihmiskunnasta, joka voi päästä paratiisiin uskon ja tahdon kautta. Pascal ajattelee, että yhteiskunta on turha ja väkivaltainen ja että vain uskon kautta ihminen voi pelastua. Sama idea löytyy Bressonin elokuvista, joissa katsoja kutsutaan kuvan ja maailman ulkopuolelle musiikin käytön ja fragmentoidun rakenteen avulla. Hahmot yrittävät parhaansa lähteäkseen pois tästä maailmasta, niin kuin esimerkiksi päähenkilö Fontaine elokuvassa Kuolemaantuomittu on karannut (1956). Siksi Bressonin estetiikkaa luonnehditaan jansenistiseksi estetiikaksi ja hänen elokuviensa nähdään kertovan transsendenssista. Bressonin tuotannon kulmakivi on tuo transsendenttinen, uskova ja tahtova marginaalihahmo.

Samantapainen kulmakivi, uskova ja tahtova marginaalihahmo, löytyy myös Kaurismäen elokuvista. Ero bressonilaiseen hahmoon on kuitenkin merkittävä: Kaurismäen teoksissa ei ole transsendenttia. Hänen elokuvissaan he, jotka onnistuvat lähtemään jonnekin, päätyvät samantyyppiseen vieraannuttavaan yhteiskuntaan, 


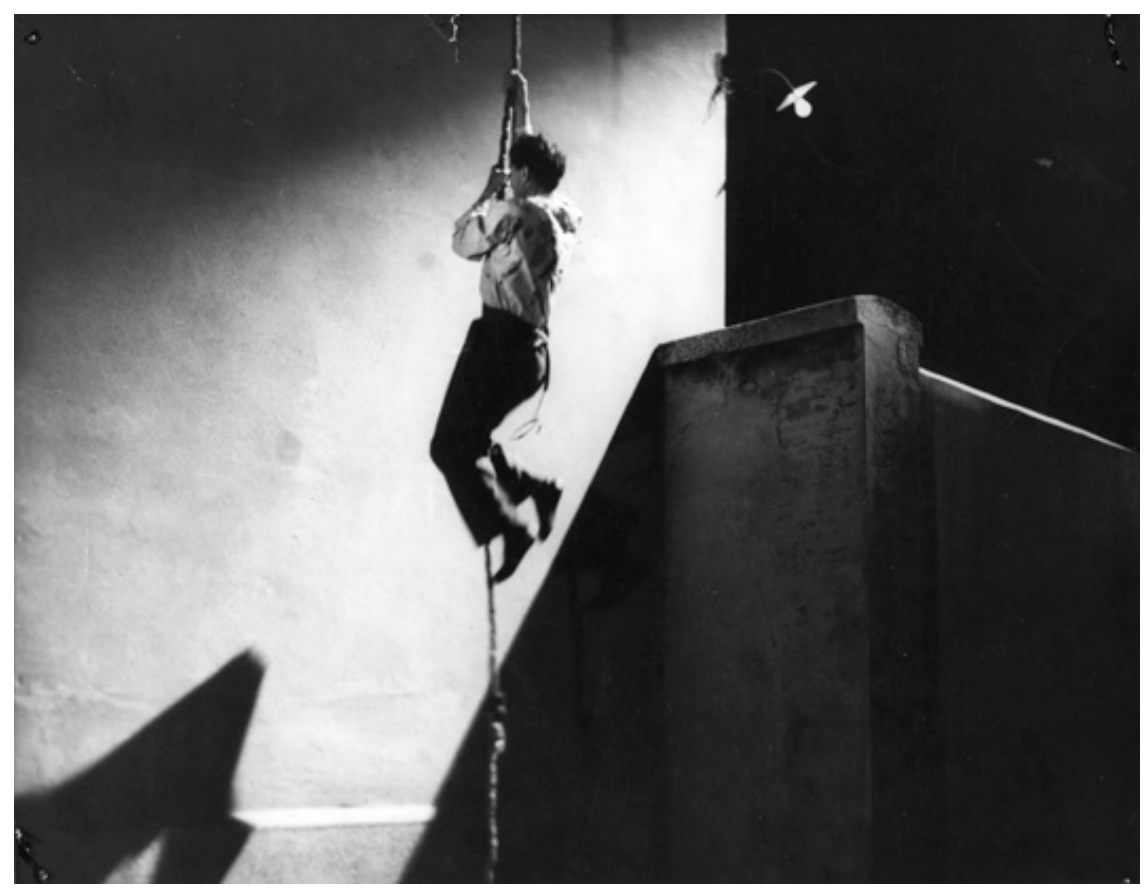

Fontaine elokuvasta Kuolemaantuomittu on karannut (1956) on esimerkki Bressonin marginaalihahmoista. Kuva: KAVI.

joka riistää marginaalissa olijoilta heidän ihmisyytensä. Lisäksi Kaurismäen keinotekoiset happy endit toimivat deus ex machinan tapaan. Ne havainnollistavat hyvin sitä ajatusta, että pakotietä modernista yhteiskunnasta ei ole, paitsi ehkä elokuvissa tai kuolemassa. Siten Kaurismäen päähenkilöt ovat läsnä olevia, tämänpuoleisia. Jos he haluavat saada kunnollisen elämän, heidän pitää taistella epäreilua yhteiskuntaa vastaan tai jopa rakentaa itse oma, oikea yhteisönsä. Mutta lähtökohtaisesti Kaurismäki näyttää yhteiskunnan marginaali-ihmisiä, joilla ei ole muita oikeuksia kuin tulla hyväksikäytetyksi. Tämä tuo mieleen Herbert Marcusen sanat:

Kansan muodostaman konservatiivisen perustan alla ja lisäksi ovat kuitenkin vielä olemassa hyljeksityt ja syrjityt, toisiin rotuihin kuuluvat ja toisen väriset riistetyt ja vainotut, työttömät ja työhön kykenemättömät. He elävät demokraattisen prosessin ulkopuolella; heidän elämänsä muodostaa välittömimmän ja todellisimman tarpeen lopettaa sietämättömät olosuhteet ja laitokset. [...] Heidän voimansa on jokaisen sellaisen mielenosoituksen takana, joka suoritetaan lain ja järjestyksen uhrien puolesta. Se tosiasia, että he alkavat kieltäytyä pelaamasta yhteistä peliä voi olla tosiasia joka osoittaa, että erään aikakauden loppu on alkanut. [...] Fasistisen kauden alussa Walter Benjamin kirjoitti: Nur um der Hoffnungslosen willen ist uns die Hoffnung gegeben. Toivo on meille annettu vain niiden tähden joilla toivoa ei ole. (Marcuse 1969, 261-262.)

Marcusen määritelmä marginaalisista ihmisistä sopii Kaurismäen elokuviin. Marcusen mukaan modernin yhteiskunnan uhrit ovat vahvoja silloin, kun he yhdistyvät ja alkavat taistella. Ajatus korostaa, että modernissa maailmassa on olemassa vain tämä hetki ja paikka. Parempia ja vaihtoehtoisia sosiaalisia tiloja voidaan rakentaa silloin, kun marginaaliset yhdistyvät joukoksi, silloin, kun ajatellaan sosiaalinen järjestelmä uusiksi lähtemällä liikkeelle yhteiskunnan rajoilta.

Kaurismäki siis jatkaa Bressonin tyylilajia, mutta ottaa huomioon sen, että koska transsendenssia ei ole, on parempi uskoa ihmiskuntaan kuin Jumalaan. Paratiisiin 
ei ole pääsyä. Marginaaliset eivät voi paeta pois tästä maailmasta, vaan heidän pitää rakentaa oma yhteisö, missä he saavat elää vapaina ja tasa-arvoisina. Itse asiassa juuri tällaista yhteiskunnallisen marginaalin käsittelyä voidaan nähdä Kaurismäen elokuvissa Mies vailla menneisyyttä (2002), Le Havre (2011) ja Toivon tuolla puolen (2017). Kaurismäki perii, etenee ja ohittaa Bressonin tuotannon uskovan näkökulman. Bressonin uskonnollisesta utopiasta tullaan Kaurismäen heterotopiaan. Heterotopia voidaan määritellä Michel Foucault'n tapaan vaihtoehtoiseksi tilaksi, jossa mielikuvitus ja ihmiset ovat vapaita ja jonka tarkoitus on antaa mahdollisuus elää erilaisessa sosiaalisessa systeemissä kuin nykykapitalistisessa yhteiskuntassa.

Voidaan nähdä miksi laiva on 1500-luvulta lähtien näihin päiviin saakka ollut sivilisaatiollemme paitsi toki tärkeä taloudellisen kehityksen väline, myös samaan aikaan mitä suurin mielikuvituksen varanto. Laiva on malliesimerkki heterotopiasta. Laivattomat kulttuurit ovat kuin lapsia, joiden vanhemmilla ei ollut parivuodetta missä leikkiä. Niinpä heidän unelmansa kuivuvat, seikkailu korvautuu vakoilulla ja merirosvojen hehkuva kauneus poliisien inhottavuudella. (Foucault 2009, 36.)

Kaurismäen vaihtoehtoinen elokuva sekä kuvaa että on heterotopiaa. Foucault'n mukaan veneet ja satamat ovat leimallinen kuva heterotopian mahdollisuuden avautumisesta. Tämä paljastaa paljon Kaurismäestä, kun otetaan huomioon, kuinka tärkeitä laivat ja veden symbolismi ovat hänen elokuvissaan. Usein päähenkilöt läh-

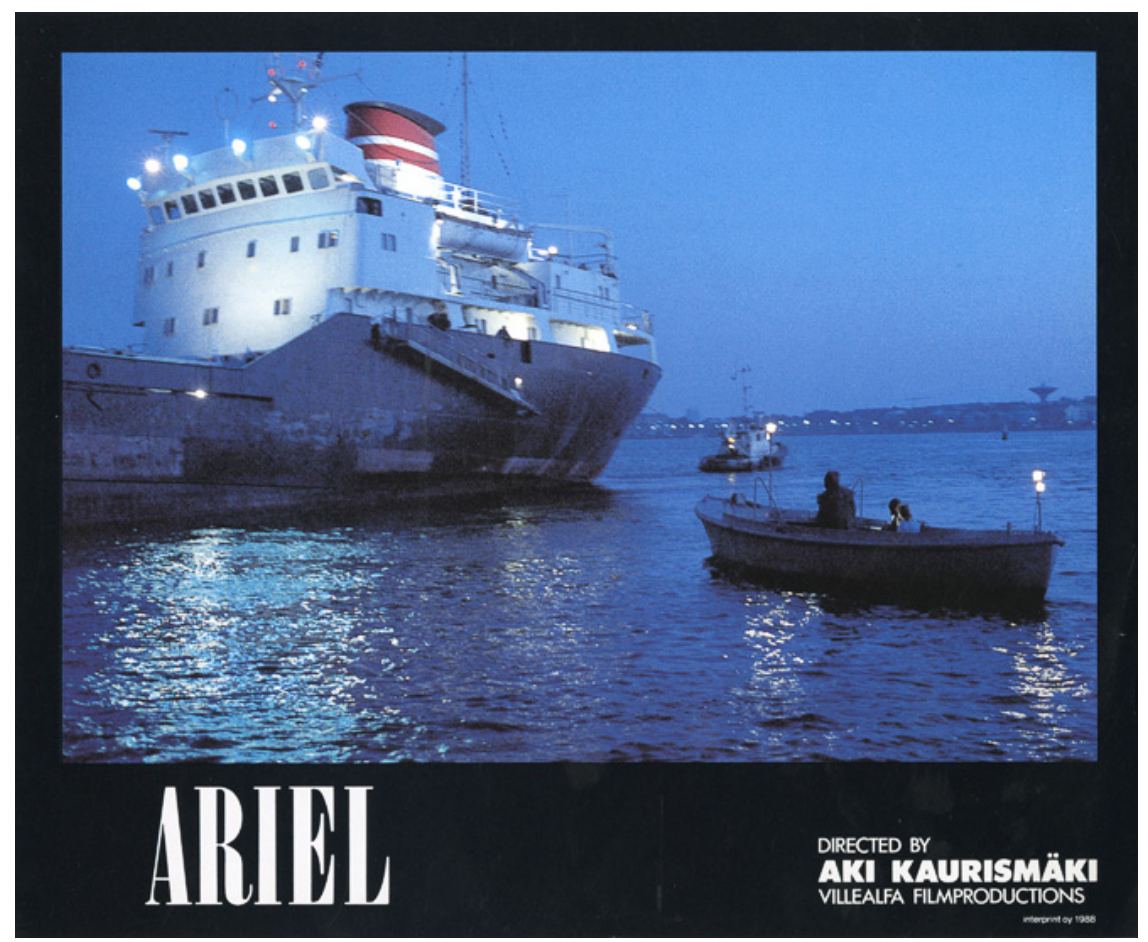

Laivojen ja vesisymbolismin merkitys näkyy erityisen hyvin Kaurismäen Ariel-elokuvassa (1988). Kuva: Kavi.

\footnotetext{
3 "On voit pourquoi le bateau a été pour notre civilisation, depuis le XVle siècle jusqu'à nos jours, à la fois non seulement, bien sûr, le plus grand instrument de développement économique, mais surtout la plus grande réserve d'imagination. Le navire, c'est l'hétérotopie par excellence. Les civilisations sans bateaux sont comme les enfants dont les parents n'auraient pas un grand lit sur lequel on puisse jouer ; leurs rêves se tarissent, l'espionnage y remplace l'aventure, et la hideur des polices la beauté ensoleillée des corsaires." Käännös: Antti Pönni.
} 
tevät parempaan paikkaan laivalla tai he saapuvat laivalla parempaan kansakuntaan. Tämä näkyy erittäin hyvin elokuvissa Ariel (1988) ja Toivon tuolla puolen (2017). Ensin mainitussa henkilöhahmot karkaavat laivalla pois Suomesta, jossa heidät halutaan vangita. Jälkimmäisessä Khaled pääsee laivalla turvaan Suomeen, missä hänellä on mahdollisuus löytää vapaus ja rauha muiden marginaalisten kanssa. Samalla logiikalla elokuvassa Mies vailla menneisyyttä (2002) päähenkilö M löytää apua, ystäviä ja uuden elämän sataman köyhien asukkaiden ansiosta. Tässä mielessä ei ole myöskään yllättävää, että Kaurismäen uusinta trilogiaa kutsutaan satamatrilogiaksi. Laivojen, veden ja satamien metaforiikka on toki vain yksi esimerkki heterotopioista Kaurismäen elokuvissa, vaikka ne yleensä liittyvätkin samantyyppisiin marginaalitiloihin.

\section{Lopuksi}

Kaurismäki antaa Bressonin elokuville analyyttisen ja teoreettisen selityksen kirjoituksessaan ja elokuviensa avulla. Hänen näkökulmansa maailmaan ja hänen elokuvallinen diskurssinsa sekä tyylilajinsa toisintavat, uudistavat ja omalla tavallaan myös parantavat Bressonin tyyliä. Ohjaajat rakentavat melodraamatyylilajin pohjalta ja omasta marginaalistaan käsin omintakeista näkökulmaa elokuvataiteeseen ja nykypäivän järjestelmään. Kuten Bresson rakensi elokuviensa kautta Pascalin tyyppistä utopiaa, Kaurismäki luo heterotopioita modernille yhteiskunnalle. Tekstissään Kaurismäki myöntää: "Kaiken kaikkiaan en olisi ikinä pärjännyt hengissä tässä jumalan hylkäämässä maailmassa ilman Mr. Bressonin realistisia valheita, joista tulen olemaan kiitollinen siihen päivään asti jolloin kuolen ja sen jälkeenkin." (von Bagh 2006, 90). Meidän on vuorostamme oltava Kaurismäelle kiitollisia mahdollisuudesta nähdä Bressonin elokuvat uusin silmin ja muistutuksesta, että tässä maailmassa on meillekin toivoa, ehkäpä jopa Happy end.

\section{Lähteet}

Ayfre, Amédée (1964) Conversion aux images? Les images et Dieu, les images et l'homme. Paris: Cerf.

Bagh, Peter von (2006) Aki Kaurismäki (Le Havrella täydennetty laitos). Helsinki: WSOY.

Bagh, Peter von (1999) "Portrait d'un ouvrier". Teoksessa Sophie Nezick, Contre Bande Aki Kaurismäki. 5, Paris: Université de Paris 1 - Panthéon-Sorbonne, 15-32.

Bazin, André (1958) Qu'est-ce que le cinéma? Paris: Cerf.

Behar, Henri (1990) Le Monde, 16. kesäkuuta 1990.

Bresson, Robert (1975) Notes sur le cinématographe. Paris : Gallimard.

Bresson, Robert \& al. (2013) Bresson par Bresson: Entretiens (1943-1983) rassemblés par Mylène Bresson. Paris: Flammarion.

Burnett, Colin (2016) The Invention of Robert Bresson: The Auteur and His Market. Indianapolis: Indiana University Press.

Dahan, Danielle (2004) Robert Bresson: une téléologie du silence. Heidelberg: Neckar, Universitätsverlag Winter.

Ezra, Elizabeth \& Rowden, Terry (2006) Transnational Cinema, The Film Reader. 1. Edition. London \& New York: Routledge.

Foucault, Michel (2009) Le corps utopique suivi de Les hétérotopies. Paris : Nouvelles Editions Lignes.

Hyttinen, Pertti (toim.) (1989) Merkintöjä Robert Bressonista. Tutkimuksia/Chydenius-instituutti. Kokkola: Chydenius-instituutin kannatusyhdistys.

Kaurismäki, Aki (1998) "Robert Bresson - A Wolf". Teoksessa James Quandt (toim.) Robert Bresson. Toronto: Toronto International Film Festival. 
Kaurismäki, Aki (2006) "Robert Bresson - Susi". Teoksessa Peter von Bagh, Aki Kaurismäki (Le Havrella täydennetty laitos). Helsinki: WSOY.

Kyösola, Satu \& Leutrat, Jean-Louis (2001) Des ombres et des nuages, dynamiques mélancoliques dans l'œuvre d'Aki Kaurismäki. Thèse de Doctorat d'Etat. Université de la Sorbonne Nouvelle, Paris III.

Lumirae, Pertti (1983) "Teurastajan painajaisuni". Suomen Sosialidemokraatti, 3. joulukuuta 1983.

Marcuse, Herbert (1969) Yksiulotteinen ihminen: teollisen yhteiskunnan tarkastelua. Helsinki: Weilin + Göös.

Nestingen, Andrew (ed.) (2004) "In Search of Aki Kaurismäki: Aesthetics and Contexts". Journal of Finnish Studies, Volume 8, Number 2 (Special issue).

Nestingen, Andrew (2013) The cinema of Aki Kaurismäki: Contrarian stories. London \& New York: Wallflower Press.

Pascal, Blaise (2004 [1670]) Les pensées. Paris: Folio.

Pecquet, Frank (1999) "Le mouvement de la vie: La musique dans les films de Kaurismäki". Teoksessa Sophie Nezick, Contre Bande Aki Kaurismäki. 5, Paris: Université de Paris 1 - Panthéon-Sorbonne, 119-128.

Prédal, René (1992) "Robert Bresson, l'aventure intérieure". L'Avant-Scéne Cinéma, n. 408/409, janvier/ février 1992, 1-38.

Price, Brian (2011) Neither God Nor Master: Robert Bresson and Radical Politics. Minneapolis: University of Minnesota Press.

Pönni, Antti (2005) Uusi kirjoitus: Robert Bresson elokuvateoreetikkona. Lisensiaatintutkimus, mediatutkimus, Turun yliopisto.

Quandt, James (ed.) (1998) Robert Bresson. Toronto: Toronto International Film Festival.

Schrader, Paul (1972) Transcendental Style in Film. New York: Da Capo Press.

Sontag, Susan (1964) "Spiritual Style in the Films of Robert Bresson". Teoksessa Against Interpretation and Other Essays. New York: Farrar Straus \& Giroux.

Thirard, Paul-Louis (1990) Positif, n³61, kesäkuu 1990.

Toiviainen, Sakari (1992) Suurinta elämässä: Elokuvamelodraaman kulta-aika. Helsinki: VAPK-kustannus. Trémois, Claude Marie (1990) "Sombre finnois". Telerama, n²103, 2. toukokuu 1990

Zamour, Françoise (2016) Le mélodrame dans le cinéma contemporain: Une fabrique de peuples. Rennes: Presses universitaires de Rennes.

\section{Elokuvat}

Bresson, Robert, 1951, Papin päiväkirja (Journal d'un curé de campagne), Ranska.

- - , 1956, Kuolemaantuomittu on karannut (Un condamné à mort s'est échappé), Ranska.

- - 1959, Taskuvaras (Pickpocket), Ranska.

- -, 1966, Au hasard Balthazar, Ranska.

- -, 1967, Mouchette, raiskattu (Mouchette), Ranska.

- - , 1969, Suloinen nainen (Une Femme douce), Ranska.

- -, 1971, Neljä yötä Pariisissa (Quatre nuits d'un rêveur), Ranska.

- - , 1977, Paholainen luultavasti (Le Diable probablement), Ranska.

- - 1983, Raha (L'Argent), Ranska.

Kaurismäki, Aki, 1983, Rikos ja rangaistus, Suomi.

- - 1986, Varjoja paratiisissa, Suomi.

,-- 1988 , Ariel, Suomi.

- - 1990, Tulitikkutehtaan tyttö, Suomi/Ruotsi.

- - 1992, Boheemielämä, Suomi.

- - , 2002, Mies vailla menneisyyttä, Suomi/Ranska/Saksa.

- - , 2006, Laitakaupungin valot, Suomi.

- - , 2012, Le Havre, Suomi/Ranska/Saksa.

,-- 2017, Toivon tuolla puolen, Suomi/Saksa.

Sirk, Douglas, 1959, Suurinta elämässä (Imitation of Life), Yhdysvallat. 